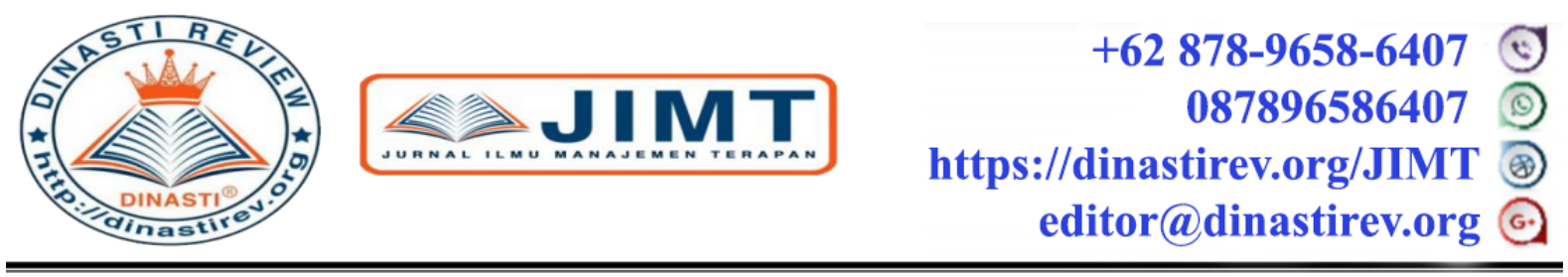

\title{
PENGARUH STRESS KERJA DAN KOMPENSASI TERHADAP KINERJA KARYAWAN DENGAN MOTIVASI KERJA SEBAGAI VARIABEL INTERVENING PADA MANDIRI UTAMA FINANCE
}

\author{
Robby Dharma ${ }^{1}$, Dori Mittra Candana ${ }^{2}$, Sancia Arilla ${ }^{3}$ \\ ${ }^{1,2,3)}$ Universitas Putra Indonesia YPTK Padang, Sumatera Barat, Indonesia
}

\begin{tabular}{|c|c|}
\hline $\begin{array}{c}\text { ARTICLE INFORMATION } \\
\text { Received: 28 April } 2020 \\
\text { Revised: 27 Juni } 2020 \\
\text { Issued: 2 Agustus } 2020 \\
\text { Corresponding Author: First author } \\
\text { E-mail: } \\
\text { robby_dharma@upiyptk.ac.id }\end{array}$ & 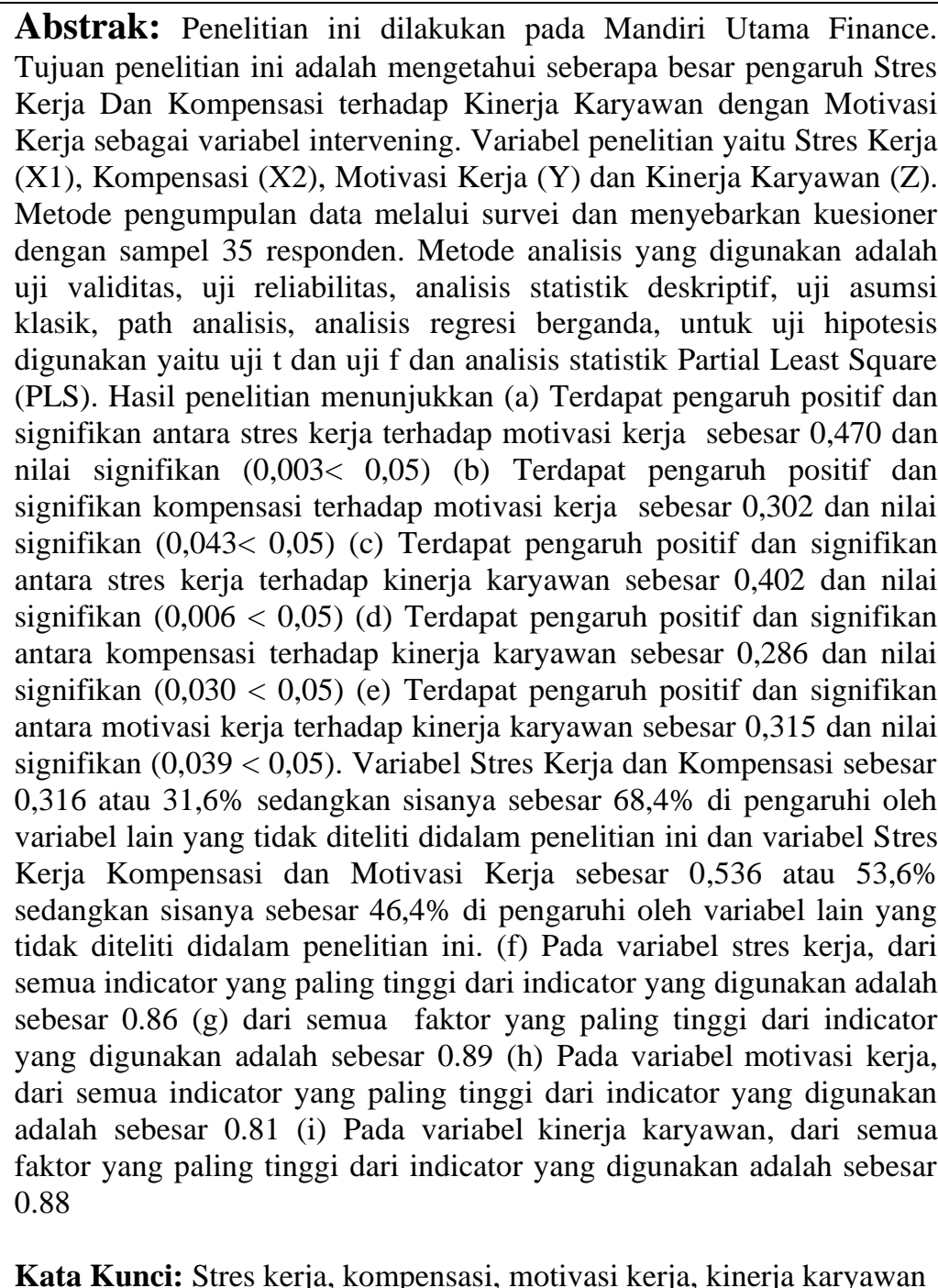 \\
\hline
\end{tabular}

\section{PENDAHULUAN}

Sumber daya manusia (SDM) merupakan faktor terpenting dalam usaha pencapaian keberhasilan organisasi. Tantangan utama yang dihadapi oleh organisasi pada masa sekarang ini dan untuk masa yang akan datang adalah bagaimana mempersiapkan SDM yang berkualitas, inovatif dan mempunyai kreatifitas tinggi. Dalam pendekatan organisasi dan 
manajemen sumberdaya manusia, persaingan bisnis yang meningkat akan memaksa organisasi untuk memasukan masalah kualitas sumberdaya manusia ke dalam strategi pengembangan organisasi. Tantangan yang dihadapi manajemen saat ini yang paling serius adalah untuk mencapai tujuan dan kelangsungan hidup perusahaan yang sangat dipengaruhi oleh kualitas kinerja sumber daya manusia yang ada di dalamnya.kinerja atau performance merupakan gambaran mengenai tingkat pencapaian pelaksaan suatu program kegiatan atau kebijakan dalam mewujudkan sasaran, tujuan, visi, dan misi organisasi yang dituangkan melalui perencanaan strategis suatu organisasi. Kinerja dapat diketahui dan diukur jika individu atau sekelompok karyawan telah mempunyai kriteria atau standar keberhasilan tolak ukur yang telah ditetapkan oleh organisasi.

Motivasi kerja disinyalir sangat berpengaruh terhadap kinerja karyawan. Motivasi kerja merupakan suatu dorongan yang menjadi dasar seseorang melakukan sesuatu atau bekerja. Seseorang yang termotivasi, yaitu orang yang melakukan upaya substansial, guna menunjang tujuan-tujuan produksi kesatuan kerjanya, dan organisasi dimana ia bekerja. Salah satu aspek yang dapat menunjang keberhasilan karyawan dalam mencapai kesuksesan bekerja adalah stres kerja yang rendah dan tidak berlebihan.Stres pada karyawan dapat berdampak pada kinerja karyawan. Jika beban yang dirasakan karyawan terlalu berat, karyawan akan mengalami hambatan dalam berfikir dan terganggunya kesehatan.

Tingkat kompensasi karyawan menentukan skala kehidupannya, sedangkan kompensasi nonfinansial menunjukkan status, martabat dan harga diri mereka. Jadi jika para karyawan memandang kompensasi mereka tidak memadai maka, prestasi kerja, motivasi dan kepuasan kerja mereka bisa turun secara dramatis dan mereka akan mengalami stres kerja yang meningkat yang membuat karyawan tidak termotivasi dalam melakukan pekerjaan.

Mandiri Utama Finance merupakan anak dari perusahaan mandiri yang didirikan pada tahun 2015 yang bergerak dalam bidang multi otomotif atau multi pembiayaan,dimana mandiri utama finance memiliki 3 lapisan struktur organisasi yaitu manajer (kepala cabang), supervisor (pembantu kepala cabang yang memiliki bawahan langsung) dan staf, mandiri utama finance memiliki visi yaitu menjadi perusahaan pembiayaan terbaik dikota padang dengan misi dapat diakui menjadi sebuah perusahaan leasing dengan target minimal masuk 5 besar dari setiap perusahaan leasing yang ada dikota padang. 


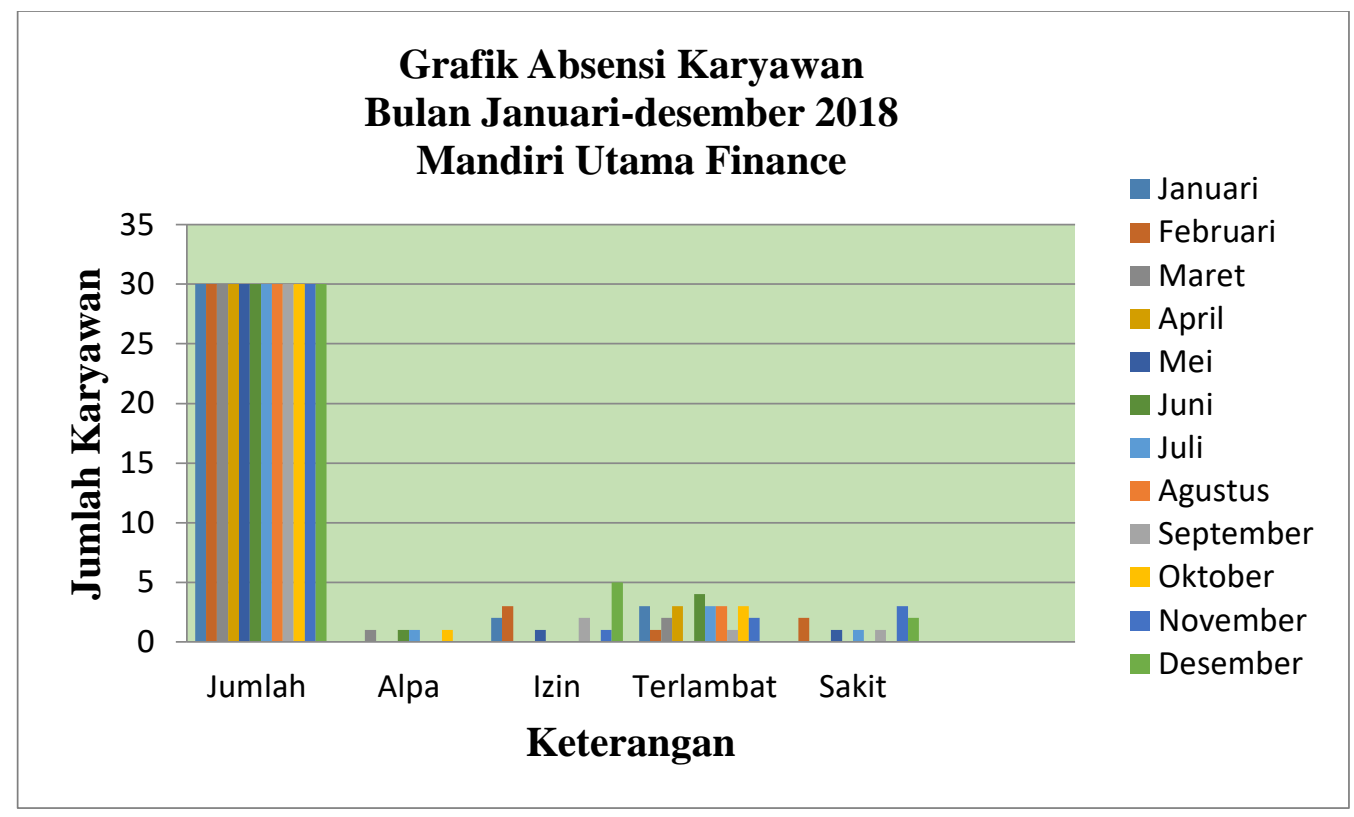

\section{Grafik 1. absensi mandiri utama finance}

\section{Sumber : Mandiri Utama Finance}

Dari absensi karyawan Mandiri Utama Finance bulan januari-desember 2018 dapat dilihat bahwa masih banyaknya jumlah karyawan yang terlambat .Absensi tertinggi pada bulan desember yaitu 5 orang terlambat dan 2 orang sakit. Dimulai pada bulan januari tingkat absensi karyawan yaitu 2 orang izin dan 3 orang terlambat, pada bulan februari 3 orang izin, 1 orang terlambat dan 2 orang sakit, pada bulan maret 1 orang alfa dan 2 orang terlambat, pada bulan april 3 orang terlambat, pada bulan mei 1 orang izin, pada bulan juni 1 orang alfa dan 4 orang terlambat, pada bulan juli 1 orang alfa dan 3 orang terlambat, pada bulan agustus 3 orang terlambat,pada bulan September 2 orang izin, 1 orang terlambat dan 1 orang sakit, pada bulan oktober terdapat 1 orang alfa, 3 orang terlambat, pada bulan November terdapat 1 orang izin, 2 orang terlambat dan 3 orang sakit, dan terakhir pada bulan desember terdapat 5 orang izin dan 2 orang sakit.

Berdasarkan hasil rekapitulasi absensi karyawan dari bulan januari sampai dengan bulan desember 2018 diatas, terlihat bahwa tingkat absensi karyawan masih cukup tinggi. Untuk target maksimal jumlah absensi sendiri, mandiri utama finance menetapkan bahwa tidak ada karyawan yang terlambat. Jadi ketika cukup tingginya tingkat absensi karyawan terutama masih cukup banyak karyawan yang terlambat, hal ini bisa disebabkan oleh kurangnya kepedulian perusahaan kepada karyawan yang kurang memperhatikan keadaan dan kebutuhan karyawan.

Sumber daya manusia yang kompeten dengan kinerja yang baik, dapat menunjang keberhasilan bisnis. Sebaliknya, sumber daya manusia yang tidak kompeten dan kinerja yang buruk merupakan masalah kompetitif yang dapat menempatkan perusahaan akan mengalami kerugian. Agar sistem ini berjalan tentu dalam pengelolaannya harus memperhatikan beberapa aspek penting seperti kepemiminan, motivasi, lingkungan kerja, kinerja dan aspek-aspek lainnya (Istiani, 2017). 
Karyawan bagian akuntansi cenderung mengalami stres kerja yang tinggi karena sebagian waktu mereka dihabiskan di tempat kerja dan dengan pekerjaan yang sama. Oleh karena itu perusahaan perlu mengidentifikasikan dan menyediakan umpan balik berupa kompensasi dan pemberian motivasi yang baik bisa membantu organisasi dalam pengambilan keputusan yang akan berdampak pada kinerja perusahaan, semakin tinggi respon umpan balik yang dilakukan perusahaan kepada karyawan akan semakin baik pula kinerja perusahaan tersebut. Secara umum, kinerja karyawan diyakini dipengaruhi oleh motivasi apabila mereka percaya bahwa kinerja mereka akan dikenal dan dihargai (Wibowo, 2016), kinerja baik yang diberikan karyawan untuk perusahaan memperoleh imbalan jasa (kompensasi) yang sesuai, dan berkurang nya stres kerja yang merupakan suatu keadaan atau kondisi ketegangan yang mempengaruhi emosi, proses berfikir, dan kondisi seseorang menjadi tantangan lebih lagi bagi karyawan.

Setiap karyawan yang ada pada mandiri utama finace pasti diperhadapkan dengan tekanan kerja yang mungkin dapat menyebabkan stres kerja pada karyawan, tapi hal tersebut merupakan suatu hal yang baik karena dengan adanya tekanan atau stres ringan itu dapat membuat mereka lebih giat lagi dalam pekerjaannya dan dapat meningkatkan kinerja mereka dalam bekerja. Penelitian dari Setyowati Subroto (2017) dalam hasil penelitiannya terdapat pengaruh yang positif Stres Kerja Terhadap Kinerja Karyawan Penelitian dari Riandy (2016) dan Tri Wartono (2017), dalam hasil penelitiannya menunjukkan adanya pengaruh yang signifikan antara stres kerja terhadap kinerja karyawan.

Menurut Zulhadi (2017) bahwa faktor yang harus dimiliki perusahaan selain kepemimpinan ialah kompensasi, kompensasi merupakan faktor yang harus diperhatikan untuk menciptakan kinerja karyawan yang baik. pemberian kompensasi yang sesuai diharapkan dapat mengahasilkan kinerja karyawan yang baik. Jesslyn Halim Dan Fransisca Andreani (2017) dan Anik Irawati (2018) mengungkapkan hal berbeda dengan zulhadi ia berpendapat bahwa kompensasi tidak memiliki pengaruh yang positif terhadap kinerja karyawan, kompensasi yang merupakan balas jasa atas prestasi yang dicapai karyawan untuk dirinya dan juga berdampak pada perusahaan tidak memberikan pengaruh pengaruh yang positif terhadap kinerja karyawan. Dikarenakan terdapat individu yang memiliki kinerja tinggi karena mengharapkan kompensasi, namun juga terdapat individu yang berkinerja tinggi dipengaruhi oleh faktor lainnya.

Yang menjadi penyebab kurang optimalnya kinerja karyawan adalah stres kerja yang cukup meningkat karena kompensasi yang kurang maksimal hal ini disebabkan karena motivasi yang diberikan kurang maksimal sehingga berakibat pada kinerja karyawan Mandiri Utama Finance. tingkat keterlambatan karyawan pada tahun 2018 cukup tinggi ditunjukan karena kompensasi yang kurang maksimal yang mengakibatkan stres kerja karyawan meningkat karena kurangnya motivasi terhadap karyawan, berdasarkan hasil observasi dan wawancara yang dilakukan hal tersebut terjadi karena terdapat beberapa fenomena pada mandiri utama finance yaitu, kondisi pekerjaan masih rendah, ketidakjelasan peran masih ada yang belum maksimal, faktor interpersonal masih kurang, dalam perkembangan karir masih belum maksimal untuk regenerasi secara posisi atau jabatannya, system gaji, bonus dan insentif yang diterima oleh karyawan masih banyak yang belum maksimal, kebutuhan untuk berprestasi terjadi pada karyawan masih rendah,pergaulan yang terjadi diantara karyawan 
masih belum maksimal, metode penilaian berprientasi masa depan karyawan masih belum maksimal, kualitas kerja karyawan masih belum maksimal, kuantitas kerja pada karyawan masih belum maksimal, kerjasama antar karyawan belum maksimal karena masih ada salah paham antar karyawan, tanggung jawab karyawan masih belum maksimal terutama dalam bidang marketing, insiatif karyawan terhadap pekerjaannya masih belum maksimal.

\section{KAJIAN PUSTAKA \\ Kinerja Karyawan}

Konsep kinerja atau prestasi kerja merupakan singkatan dari kinetika energi kerja yang padanannya dalam bahasa inggris adalah Performance (Wirawan , 2012: 5) dalam buku

\section{Arif Yusuf Hamali.}

\section{Dimensi Dan Indikator Kinerja Karyawan}

a.) Target. Target merupakan indikator terhadap pemenuhan jumlah barang, pekerjaan, atau jumlah uang yang dihasilkan.

Indikator :

1. Fokus pada target

2. Menentang dan realistis

3. Memenuhi kuantitas

4. Pelanggan (internal dan eksternal) puas atas kuantitas yang dihasilkan

b.) Kualitas. Kualitas adalah elemen penting, karena kualitas yang dihasilkan menjadi kekuatan dalam mempertahankan loyalitas pelanggan

Indikator :

1. kualitas sesuai dengan standar yang sudah ditetapkan

2. Anggota memiliki komitmen tentang kualitas

3. Memiliki prosedur tentang pencapaian kualitas

4. Pelanggan (internal dan eksternal) puas atas kualitas yang dihasilkan

c.) Waktu penyelesaian. Penyelesaian yang tepat waktu membuat kepastian distribusi dan penyerahan pekerjaan menjadi pasti, ini adalah modal untuk membuat kepercayaan pelanggan.

Indikator :

1. Pekerjaan selesai tepat waktu

2. Pelanggan puas atas waktu penyelesaian

3. Anggota berkomitmen terhadap pentingnya ketepatan waktu

d.) Taat Asas. Tidak saja harus memenuhi target, kualitas dan tepat waktu tapi juga harus dilakukan dengan cara yang benar, transaparan dan dapat dipertanggungjawabkan

Indikator :

1. Dilakukan dengan cara yang benar

2. Transfaran dan dapat dipertanggungjawabkan

\section{Motivasi Kerja}

Istilah motivasi (motivation) berasal dari bahasa latin,yaitu "movere" yang artinya "menggerakan”(to move). Gray (Dalam Winardi, 2011: 2) mendefinsikan motivasi sebagai hasil sejumlah proses yang bersifat internal tau eksternal bagi seorang individu,yang 
menyebabkan timbulnya sikap antuasisme dan persistence dalam hal melaksanakan kegiatankegiatan tertentu.

\section{Dimensi Dan Indikator Motivasi Kerja}

Menurut Dr. Emron Edison dkk (2016) menjelaskan bahwa dimensi dan indikator yang digunakan untuk mengukur motivasi dengan mengembangkan teori dari Abraham Maslow, yaitu :

\section{a. Kebutuhan Fisiologis}

1. Tingkat kebutuhan hidup yang diterima karyawan

2. Tingkat terpenuhinya kebutuhan karyawan untuk pendidikkan anak- anaknya

\section{b. Kebutuhan Rasa Aman}

1. Tingkat penerimaan (perasaan yang menyenangkan) terhadap rekan kerja

2. Tingkat penerimaan (perasaan yang menyenangkan) terhadap rekan kerja

3. Tingkat kenyamanan suasana dan lingkungan kerja

4. Tingkat kepastian program pensiun atau hari tuayaitu kebutuhan berkuasa, ingin memiliki status sosial yang lebih tinggi dan mendapat pengakuan

\section{c. Kebutuhan Untuk Disukai}

1. Tingkat perhatian pemimpin terhadap pekerjaan karyawannya

2. Tingkat perhatian pemimpin secara personal tentang persoalan pribadi yang dihadapi karyawannya

3. Tingkat persamaan karyawan dimata pemimpin

d. Kebutuhan Harga Diri

1. Tingkat perlakuan dan kesopanan pemimpin terhadap karyawannya

2. Tingkat penghargaan atau perhatian pemimpin terhadap prestasi yang didapatkan oleh karyawannya.

\section{e.) Kebutuhan Pengembangan Diri}

1.Tingkat dukungan pemimpin untuk pengembanganDiri karyawan

\section{Stres Kerja}

Menurut (Hamali, 2016) "Stres di tempat kerja adalah sebuah masalah kritis yang makin bertambah bagi para pekerja, majikan, dan masyarakat.

\section{Dimensi Dan Indikator Stres Kerja}

Menurut Astianto dan suprihadi (2014) dalam Muhammad Andi Prayogi 2019), yaitu:
a. Psikologis
Meliputi :
a. Cepat tersinggung
b. Tidak komunikatif
c. Banyak melamun
d. Lelah mental

b. Fisk

Meliputi :

a. Meningkatnya detak jantung 
b. Meningkatnya tekanan darah

c. Pusing

d. Sulit tidur

\section{c. Perilaku}

Meliputi :

a. Menunda pekerjaan

b. Perilaku sabotase

c. Pola makan tidak teratur

\section{Kompensasi}

Menurut Hasibuan (2017: 119) Kompensasi adalah semua pendapatan yang berbentuk uang, barang langsung atau tidak langsung yang diterima karyawan sebagai immbalan atas jasa yang diberikan kepada perusahaan

\section{Dimensi dan Indikator Kompensasi}

Menurut Dr. Emron Edison dkk (2016) dimensi dan indikator Kompensasi terdiri dari :

\section{a. Normatif}

1. Upah yang sudah memenuhi unsur minimal yang ditetapkan oleh pemerintah

2. Tunjangan jabatan yang ada sesuai dengan bobot kerja dan tanggung jawab yang telah diemban

3. Upah yang dibagikan telah sesuai dengan prestasi yang dihasilkan

4. Mendapatkan tunjangan keluarga di luar perhitungan upah minimal

5. Mendapatkan tunjangan-tunjangan lain (misalnya tunjangan lauk pauk) yang bersifat tetap setiap bulan, tanpa mengurangi UMK

6. Mendapatkan tunjangan kesehatan (BPJS) sesuai dengan ketentuan yang diatur dalam perundang-undangan

7. Mendapatkan tunjangan hari raya/keagamaan sesuai dengan ketentuan perundangundangan.

\section{b. Kebijakan}

1. Mendapatkan tunjangan makan setiap masuk kerja

2. Mendapatkan tunjangan transportasi setiap masuk bekerja

3. Mendapatkan tunjangan insentif jika memenuhi target yang sudah ditetapkan

4. Setiap tahun menerima tunjangan jasa produksi

5. Memberikan bonus yang dilakukan secara proporsional dan adil

6. Mendapatkan uang cuti tahunan dari perusahaan setiap tahun berlibur bersama seluruh anggota

7. setiap tahun berlibur bersama seluruh anggota 


\section{Kerangka Pikir}

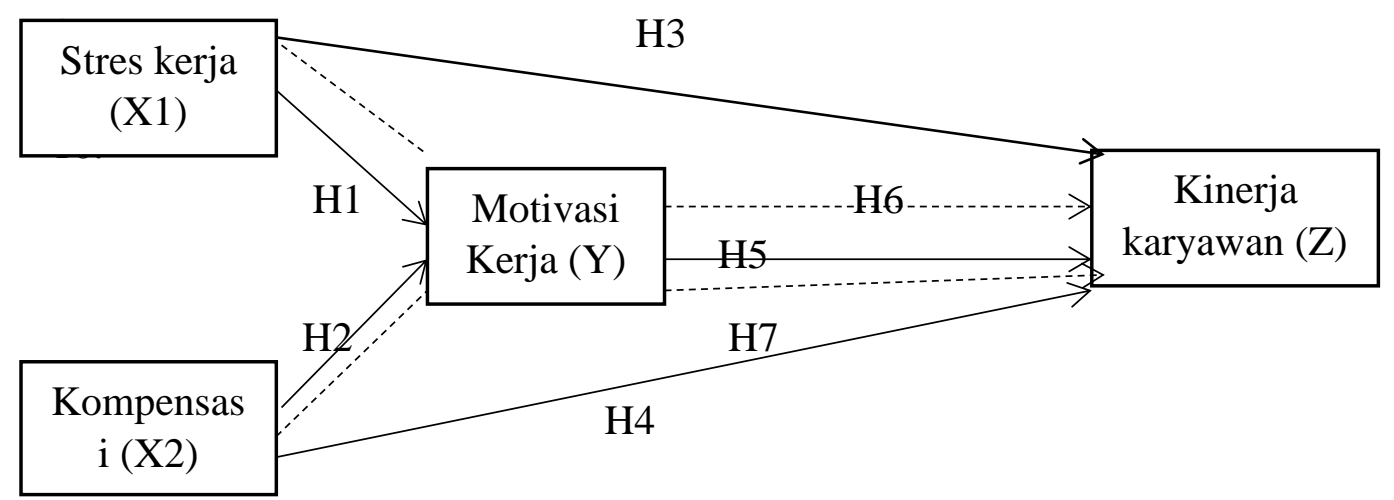

\section{Hipotesis}

H1 : Diduga Terdapat Pengaruh Stres Kerja Terhadap kinerja karyawan Pada Mandiri Utama Finance

H2 : Diduga Terdapat Pengaruh kompensasi Terhadap kinerja karyawan Pada Mandiri Utama Finance

H3 : Diduga Terdapat Pengaruh Stres Kerja Terhadap motivasi kerja Pada Mandiri Utama Finance

H4 : Diduga Terdapat Pengaruh kompensasi Terhadap motivasi kerja Pada Mandiri Utama Finance

H5 : Diduga Terdapat Pengaruh kinerja karyawan Terhadap motivasi kerja Pada Mandiri Utama Finance

H6 : Diduga Terdapat Pengaruh stres kerja Terhadap Kinerja Karyawan dengan motivasi kerja sebagai variabel intervening Pada Mandiri Utama Finance

H7 : Diduga Terdapat Pengaruh kompensasi Terhadap Kinerja Karyawan dengan motivasi kerja sebagai variabel intervening Pada Mandiri Utama Finance

\section{METODE PENELITIAN}

Penelitian Ini menggunakan metode kuantitatif dimana dalam pengolahan data menggunakan program SPSS versi 22 untuk menguji koefisien determinasi, uji t, persamaan regresi dan PLS.

\section{Populasi Dan Sampel}

Populasi dalam penelitian ini adalah seluruh karyawan mandir utama finance yang berjumlah 35 orang karyawan, Sampel dalam penelitian ini diambil dari seluruh populasi pada mandiri utama finance.

\section{HASIL DAN PEMBAHASAN}




\section{Koefisien Determinasi $\left(\mathbf{R}^{2}\right)$}

\section{Hasil Pengujian Determinasi \\ Persamaan I}

Model Summary ${ }^{b}$

\begin{tabular}{|l|r|r|r|r|}
\hline Model & \multicolumn{1}{|c|}{$\mathrm{R}$} & R Square & \multicolumn{1}{c|}{$\begin{array}{c}\text { Adjusted R } \\
\text { Square }\end{array}$} & $\begin{array}{r}\text { Std. Error of } \\
\text { the Estimate }\end{array}$ \\
\hline 1 &, $597^{\mathrm{a}}$ &, 356 &, 316 & 4,958 \\
\hline
\end{tabular}

a. Predictors: (Constant), Kompensasi, Stres Kerja

b. Dependent Variable: Motivasi Kerja

\section{Hasil Pengujian Determinasi}

Persamaan II

Model Summary ${ }^{b}$

\begin{tabular}{|l|r|r|r|r|}
\hline Model & \multicolumn{1}{|c|}{$\mathrm{R}$} & R Square & Adjusted R Square & \multicolumn{2}{|c|}{$\begin{array}{c}\text { Std. Error of the } \\
\text { Estimate }\end{array}$} \\
\hline 1 & $.759^{\mathrm{a}}$ & .577 & .536 & 5.672 \\
\hline
\end{tabular}

a. Predictors: (Constant), Motivasi Kerja, Kompensasi, Stres Kerja

b. Dependent Variable: Kinerja Karyawan

Persamaan I diperoleh angka Adjusted R Square sebesar 0,316 hal ini menunjukan bahwa sumbangan variabel Stres Kerja dan Kompensasi sebesar 0,316 atau 31,6\% sedangkan sisanya sebesar $68,4 \%$ di pengaruhi oleh variabel lain yang tidak diteliti didalam penelitian ini. Sedangkan persamaa II diperoleh angka Adjusted R Square sebesar 0,536 hal ini menunjukan bahwa sumbangan variabel Stres Kerja Kompensasi dan Motivasi Kerja sebesar 0,536 atau $53,6 \%$ sedangkan sisanya sebesar $46,4 \%$ di pengaruhi oleh variabel lain yang tidak diteliti didalam penelitian ini.

\subsection{Uji Parsial (Uji t)}

\section{Persamaan I}

\section{Hasil Pengujian Hipotesis Penelitian \\ Persamaan I}

Coefficients $^{\mathbf{a}}$

\begin{tabular}{|c|c|c|c|c|c|}
\hline \multirow{2}{*}{ Model } & \multicolumn{2}{|c|}{$\begin{array}{c}\text { Unstandardized } \\
\text { Coefficients }\end{array}$} & \multicolumn{2}{|c|}{$\begin{array}{c}\text { Standardized } \\
\text { Coefficients }\end{array}$} & \\
\cline { 2 - 4 } & $\mathrm{B}$ & $\begin{array}{c}\text { Std. } \\
\text { Error }\end{array}$ & Beta & $\mathrm{t}$ & Sig. \\
\hline $1 \quad$ (Constant) & 17.743 & 7.743 & & 2.291 & .029 \\
\hline
\end{tabular}




\begin{tabular}{|l|r|r|r|r|r|}
\hline $\begin{array}{l}\text { Stres Kerja } \\
\text { Kompensa }\end{array}$ & .453 & .138 & .470 & 3.273 & .003 \\
si & .203 & .097 & .302 & 2.107 & .043 \\
\hline
\end{tabular}

a. Dependent Variable: Motivasi

Kerja

Pengaruh Stres Kerja terhadap motivasi Kerja.

Ho : b1 = $0:$ Stres Kerja tidak berpengaruh positif dan signifikan terhadap motivasi Kerja.

Ha : b1 > 0 : Stres Kerja ber pengaruh positif dan signifikan terhadap motivasi Kerja. Hasil pengujian dengan SPSS diperoleh untuk variabel X1 (Stres Kerja), dengan thitung lebih besar dari t-tabel ( $3.273>1.697$ ) dengan menggunakan batas signifikan 0,05 , dengan tingkat signifikan $(0,003<0,05)$, yang berarti Ho ditolak Ha diterima. Dengan demikian, maka hipotesis pertama diterima.

Pengaruh Kompensasi terhadap motivasi Kerja.

Ho : b1 = 0 : Kompensasi tidak berpengaruh positif dan signifikan terhadap motivasi Kerja.

Ha : b1 > 0 : Kompensasi berpengaruh positif dan signifikan terhadap motivasi Kerja.

Hasil pengujian dengan SPSS diperoleh untuk variabel X2 ( Kompensasi ), dengan thitung lebih besar dari t-tabel ( $2.107>1.697$ ) dengan menggunakan batas signifikan 0,05 , dengan tingkat signifikan $(0,043<0,05)$, yang berarti Ho ditolak Ha diterima. Dengan demikian, maka hipotesis kedua diterima.

\section{Persamaan II}

\section{Hasil Pengujian Hipotesis Penelitian \\ Persamaan II}

Coefficients $^{\text {a }}$

\begin{tabular}{|c|c|c|c|c|c|c|}
\hline \multirow{2}{*}{\multicolumn{2}{|c|}{ Model }} & \multicolumn{2}{|c|}{$\begin{array}{l}\text { Unstandardized } \\
\text { Coefficients }\end{array}$} & \multirow{2}{*}{$\begin{array}{c}\begin{array}{c}\text { Standardized } \\
\text { Coefficients }\end{array} \\
\text { Beta }\end{array}$} & \multirow[b]{2}{*}{$\mathrm{T}$} & \multirow[b]{2}{*}{ Sig. } \\
\hline & & B & Std. Error & & & \\
\hline \multirow[t]{4}{*}{1} & (Constant) & -7.751 & 9.557 & & -.811 & .424 \\
\hline & Stres Kerja & .538 & .183 & .402 & 2.942 & .006 \\
\hline & Kompensasi & .267 & .118 & .286 & 2.268 & .030 \\
\hline & $\begin{array}{l}\text { Motivasi } \\
\text { Kerja }\end{array}$ & .437 & .202 & .315 & 2.161 & .039 \\
\hline
\end{tabular}

a. Dependent Variable: Kinerja Karyawan

Pengaruh Stres Kerja terhadap Kinerja Karyawan.

Ho : b1 = 0 : Stres Kerja tidak berpengaruh positif dan signifikan terhadap Kinerja Karyawan.

Ha : b1 > 0 : Stres Kerja berpengaruh positif dan signifikan terhadap Kinerja Karyawan. 
Hasil pengujian dengan SPSS diperoleh untuk variabel X1 (Stres Kerja ), dengan t-hitung lebih besar dari t-tabel ( $2.942>1.697$ ) dengan menggunakan batas signifikan 0,05, dengan tingkat signifikan $(0,006<0,05)$, yang berarti Ho ditolak Ha diterima. Dengan demikian, maka hipotesis ketiga diterima.

Pengaruh Kompensasi terhadap Kinerja Karyawan.

Ho : b1 = 0 : Kompensasi tidak berpengaruh positif dan signifikan terhadap Kinerja Karyawan.

Ha : b1 > 0 : Kompensasi berpengaruh positif dan signifikan terhadap Kinerja Karyawan. Hasil pengujian dengan SPSS diperoleh untuk variabel X2 ( Kompensasi ), dengan thitung lebih besar dari t-tabel ( $2.268>1.697$ ) dengan menggunakan batas signifikan 0,05 , dengan tingkat signifikan $(0,030<0,05)$, yang berarti Ho ditolak Ha diterima.

Dengan demikian, maka hipotesis keempat diterima.

Pengaruh Motivasi Kerja terhadap Kinerja Karyawan.

Ho : b1 = 0 : Kompensasi tidak berpengaruh positif dan signifikan terhadap Kinerja Karyawan.

Ha : b1 > 0 : Kompensasi berpengaruh positif dan signifikan terhadap Kinerja Karyawan. Analisis Regresi Linear Berganda Persamaan I

1. Konstanta regresi positif sebesar 17,743 artinya apabila Stres Kerja dan kompensasi ditingkatkan sebesar satu satuan, maka akan mengakibatkan kenaikan motivasi kerja sebesar 17,743

2. Koefisien regresi positif sebesar 0,470 artinya apabila Stres Kerja ditingkatkan sebesar satu satuan, dengan asumsi Kompensasi diabaikan, maka akan mengakibatkan kenaikan motivasi kerja sebesar 0,470 .

3. Koefisien regresi positif sebesar 0,302 artinya apabila Kompensasi ditingkatkan sebesar satu satuan, dengan asumsi Stres Kerja diabaikan, maka akan mengakibatkan kenaikan motivasi kerja sebesar 0,302.

\section{Analisis Regresi Linear Berganda Persamaan II}

1. Konstanta regresi negatif sebesar -7,751 artinya apabila Stres Kerja,Kompensasi dan motivasi kerja ditingkatkan sebesar satu satuan, maka akan mengakibatkan penurunan Kinerja Karyawan sebesar $-7,751$

2. Koefisien regresi positif sebesar 0,402 artinya apabila Stres Kerja ditingkatkan sebesar satu satuan, dengan asumsi Kompensasi dan motivasi kerja diabaikan, maka akan mengakibatkan kenaikan Kinerja Karyawan sebesar 0,402.

3. Koefisien regresi positif sebesar 0,286 artinya apabila Kompensasi ditingkatkan sebesar satu satuan, dengan asumsi Stres Kerja dan motivasi kerja diabaikan, maka akan mengakibatkan kenaikan Kinerja Karyawan sebesar 0,286.

4. Koefisien regresi positif sebesar 0,315 artinya apabila motivasi kerja ditingkatkan sebesar satu satuan, dengan asumsi Stres Kerja dan Kompensasi diabaikan, maka akan mengakibatkan kenaikan Kinerja Karyawan sebesar 0,315.

5. Hasil pengujian dengan SPSS diperoleh untuk variabel Z (Kompensasi ), dengan thitung lebih besar dari t-tabel ( $2.161>1.697$ ) dengan menggunakan batas signifikan 0,05 , dengan tingkat signifikan $(0,039<0,05)$, yang berarti Ho ditolak Ha diterima. Dengan demikian, maka hipotesis kelima diterima. 


\section{Uji PLS}

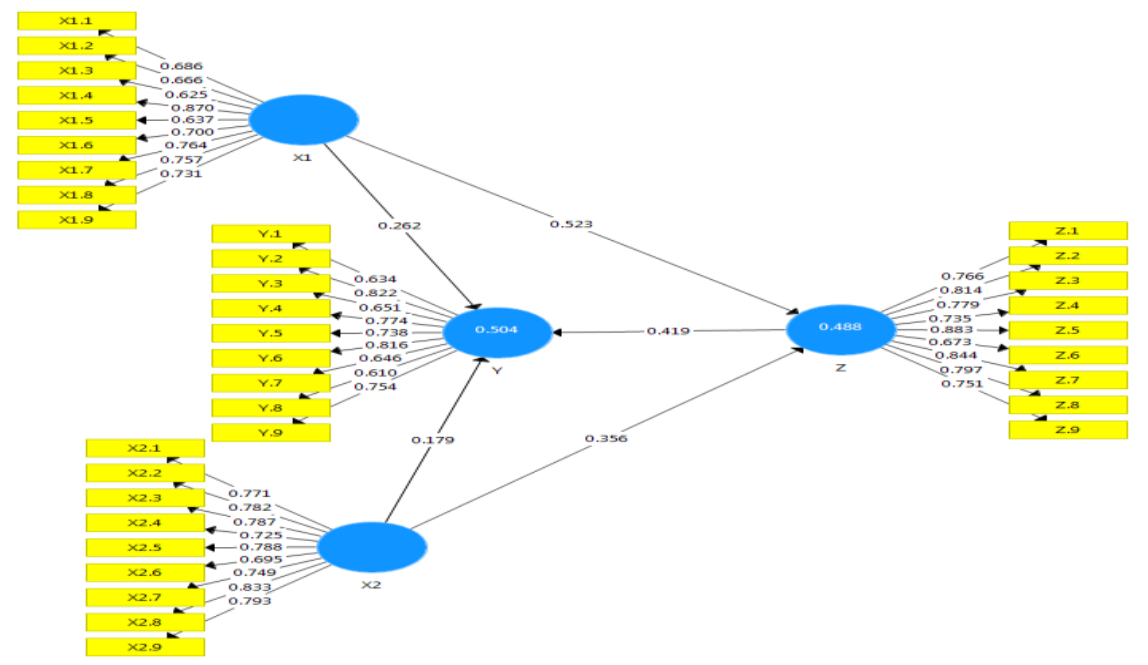

1. Pada variabel stres kerja, dari semua indicator yang ada terdapat nilai loading faktor yang paling tinggi dari indicator yang digunakan adalah sebesar 0.86 dengan indicatornya "lelah mental"

2. Pada variabel kompensasi, dari semua indicator yang ada terdapat nilai loading faktor yang paling tinggi dari indicator yang digunakan adalah sebesar 0.89 dengan indicatornya "memberikan bonus yang dilakukan secara proporsional dan adil" dan "mendapatkan tunjangan makan setiap masuk kerja"

3. Pada variabel motivasi kerja, dari semua indicator yang ada terdapat nilai loading faktor yang paling tinggi dari indicator yang digunakan adalah sebesar 0.81 dengan indicatornya "tingkat persamaan karyawan dimata pemimpin" dan "tingkat dukungan pemimpin untuk pengembangan diri karyawan"

Pada variabel kinerja karyawan, dari semua indicator yang ada terdapat nilai loading faktor yang paling tinggi dari indicator yang digunakan adalah sebesar 0.88 dengan indicatornya "pelanggan puas atas waktu penyelesaian" dan "transfaran dan dapat dipertanggungjawabkan"

\section{KESIMPULAN DAN SARAN}

Dari pembahasan pada bab-bab sebelumnya, maka dapat ditarik beberapa kesimpulan sebagai berikut :

1. Terdapat pengaruh positif dan signifikan antara Stres Kerja terhadap Motivasi Kerja Pada Mandiri Utama Finance. Hal ini dibuktikan dengan koefisien beta $(\beta)$ stres kerja terhadap motivasi kerja sebesar 0,470 dan nilai signifikan $(0,003<0,05)$,

2. Terdapat pengaruh positif dan signifikan antara Kompensasi terhadap Motivasi Kerja Pada Mandiri Utama Finance. Hal ini dibuktikan dengan koefisien beta $(\beta)$ kompensasi terhadap motivasi kerja sebesar 0,302 dan nilai signifikan $(0,043<0,05)$,

3. Terdapat pengaruh positif dan signifikan antara Stres Kerja terhadap kinerja karyawan Pada Mandiri Utama Finance. Hal ini dibuktikan dengan koefisien beta $(\beta)$ stres kerja terhadap kinerja karyawan sebesar 0,402 dan nilai signifikan $(0,006<0,05)$,

4. Terdapat pengaruh positif dan signifikan antara kompensasi terhadap kinerja karyawan Pada Mandiri Utama Finance. Hal ini dibuktikan dengan koefisien beta $(\beta)$ kompensasi terhadap kinerja karyawan sebesar 0,286 dan nilai signifikan $(0,030<0,05)$, 
5. Terdapat pengaruh positif dan signifikan antara motivasi kerja terhadap kinerja karyawan Pada Mandiri Utama Finance. Hal ini dibuktikan dengan koefisien beta $(\beta)$ motivasi kerja terhadap kinerja karyawan sebesar 0,315 dan nilai signifikan $(0,039<0,05)$,

6. Hasil analisis jalur persamaan satu sebesar 0,55>0,402 artinya hubungan tidak langsung lebih besar dari hubungan langsung, artinya Kompensasi di memediasi hubungan antara Stres Kerja terhadap Kinerja Karyawan.

7. Pada variabel stres kerja, dari semua indicator yang ada terdapat nilai loading faktor yang paling tinggi dari indicator yang digunakan adalah sebesar 0.86 dengan indicatornya "lelah mental" dan terdapat nilai loading faktor yang paling rendah adalah sebesar 0.55 dengan indikatornya "banyak melamun". Maka disimpulkan bahwa pada variabel stress kerja yang paling dominan adalah X1.4= lelah mental mampu dihadapi oleh karyawan mandiri utama finance dan X1.3=banyak melamun tidak mampu dihadapi oleh karyawan Mandiri Utama Finance.

8. Pada variabel kompensasi, dari semua indicator yang ada terdapat nilai loading faktor yang paling tinggi dari indicator yang digunakan adalah sebesar 0.89 dengan indicatornya "memberikan bonus yang dilakukan secara proporsional dan adil" dan "mendapatkan tunjangan makan setiap masuk kerja" dan terdapat nilai loading faktor yang paling rendah dari indikator yang digunakan adalah sebesar 0.67 dengan indikatornya "mendapatkan tunjangan insentif jika memenuhi target yang sudah ditetapkan" dan "Mendapatkan tunjangan keluarga di luar perhitungan upah minimal". Maka disimpulkan bahwa pada variabel kompensasi yang paling dominan adalah X2.12= "memberikan bonus yang dilakukan secara proporsional dan adil" dan X2.8= mendapatkan tunjangan makan setiap masuk kerja yang dirasakan oleh karyawan mandiri utama finance dan X2.10= mendapatkan tunjangan insentif jika memenuhi target yang sudah ditetapkan dan X2.4= Mendapatkan tunjangan keluarga di luar perhitungan upah minimal tidak dirasakan oleh karyawan Mandiri Utama Finnace.

9. Pada variabel motivasi kerja, dari semua indicator yang ada terdapat nilai loading faktor yang paling tinggi dari indicator yang digunakan adalah sebesar 0.81 dengan indicatornya "tingkat persamaan karyawan dimata pemimpin" dan "tingkat dukungan pemimpin untuk pengembangan diri karyawan" dan terdapat nilai loading faktor yang paling rendah adalah 0.58 dengan indikatornya "tingkat kebutuhan hidup yang diterima karyawan" Maka disimpulkan bahwa pada variabel kompensasi yang paling dominan adalah Y.9= tingkat persamaan karyawan dimata pemimpin dan Y.11 = tingkat dukungan pemimpin untuk pengembangan diri karyawan yang dimiliki oleh karyawan mandiri utama finance dan $\mathrm{Y} 1=$ tingkat kebutuhan hidup yang diterima karyawan tidak dimiliki oleh karyawan Mandiri Utama Finance.

10. Pada variabel kinerja karyawan, dari semua indicator yang ada terdapat nilai loading faktor yang paling tinggi dari indicator yang digunakan adalah sebesar 0.88 dengan indicatornya "pelanggan puas atas waktu penyelesaian" dan "transfaran dan dapat dipertanggungjawabkan" dan terdapat nilai loading faktor yang paling rendah adalah sebesar 0.71 dengan indikatornya "memenuhi kuantitas". Maka disimpulkan bahwa pada variabel kinerja karyawan yang paling dominan adalah Z.10= pelanggan puas atas waktu penyelesaian dan $\mathrm{Z}=13$ = transfaran dan dapat dipertanggungjawabkan diterapkan oleh 
mandiri utama finance dan Z3= memenuhi kuantitas tidak diterapkan oleh karyawan mandiri utama finance.

\section{Saran}

Berdasarkan kesimpulan yang telah dibuat, maka penulis mengemukakan beberapa saran kepada Perusahaan :

Bagi Perusahaan

Untuk PT. Mandiri Utama Finance harus lebih meningkatkan Stres Kerja agar menghasilkan Kinerja Karyawan yang memuaskan.

Untuk PT. Mandiri Utama Finance harus lebih meningkatkan Kompensasi agar menghasilkan Kinerja Karyawan yang memuaskan.

Hasil analisis jalur persamaan kedua sebesar 0,381 > 0,286 artinya hubungan tidak langsung lebih besar dari hubungan langsung Kompensasi di memediasi hubungan antara Kompensasi terhadap Kinerja Karyawan

\section{DAFTAR RUJUKAN}

Abdurahman, maman, muhidin, sambas ali \& somantri, ating. (2011). Dasardasar metode statistika untuk penelitian. Bandung: cv pustaka setia.

Almasri, m. N. (2016). Manajemen sumber daya manusia : implementasi dalam pendidikan islam. Jurnal penelitian sosial keagamaan.

Arif yusuf hamali. (2016), pemahaman manajemen sumber daya manusia. yogyakarta : pt. Buku seru.

Badriyah, mila. 2015. Manajemen sumber daya manusia. Bandung : cv pustaka setia.

Dr, emron edison dkk. 2016. Manajemen sumber daya manusia.bandung : alfabeta, cv

Edy sutrisno. 2010. Manajemen sumber daya manusia. Edisi pertama. Cetakan pertama. Jakarta : penerbit kencana

Hamali, a. Y. (2016). Pemahaman manajemen sumber daya manusia (strategi mengelola karyawan) (pertama). Yogyakarta: caps (center for academic publishing service).

Hasibuan, malayu s.p. 2016. Manajemen sumber daya manusia. Edisi revisi. Jakarta: penerbit pt bumi aksara.

Hasibuan, malayu s.p.. 2017. Manajemen sumber daya manusia. Edisi revisi. jakarta: bumi aksara.

Noor, juliansyah. 2014. Metodologi penelitian. Jakarta: kencana prenada media group

Sondang p siagian, 2016. "manajemen sumber daya manusia”. Jakarta : bumi aksara

Sugiyono. (2016). Metode penelitian kuantitatif, kualitatif dan $r \& d$. Bandung: pt alfabet.

Sutrisno, edy. 2015. Manajemen sumber daya manusia. Jakarta: kencana prenada media group.

Wibowo. 2013. Manajemen kinerja. Jakarta: rajawali pers

Wibowo, 2016. Manajemen kinerja, edisi kelima, pt.rajagrafindo persada jakarta14240. 
Arifin, h. M. (2015). The influence of competence, motivation, and organisational culture to high school teacher job satisfaction and performance. International education studies, $8(1)$, $38-45$.

Brahim, a. (2016). Analisis implementasi manajemen kualitas dari kinerja operasional pada industri ekstraktif di sulawesi utara. Jurnal emba: jurnal riset ekonomi, manajemen, bisnis dan akuntansi, 4(2).

Hasibuan, n. M. (2019). Pengaruh kepemimpinan islam, kompensasi, dan pengembangan produk terhadap kinerja karyawan bank pembiayaan rakyat syari'ah bandar lampung. Psyche: jurnal psikologi, 1(2), 85-95.

Khoiriah, n., hs, s. W. L., \& utami, w. (2019). Pengaruh kompensasi dan lingkungan kerja terhadap kinerja karyawan dengan motivasi kerja sebagai variabel intervening pada pt. Perkebunan nusantara xii bagian pengolahan karet kebun kotta blater jember. E-journal ekonomi bisnis dan akuntansi, 6(2), 141-146.

Yulianti, p., \& utami, w. S. (2019). Pengaruh kompensasi terhadap kinerja karyawan pt. Bfi finance dengan motivasi kerja sebagai variabel intervening. Jurnal ekonomi dan bisnis dharma andalas, 21(1), 97-106.

Qadoos zafar, a. A., hameed, t., \& toqeerilyas, h. I. Y. (2015). The influence of job stress on employees performance in pakistan. American journal of social science research, 1(4), 221225.

Setyowati, s. (2017). Analisis pengaruh locus of control dan stres kerja terhadap kinerja karyawan. Jurnal ilmiah manajemen dan bisnis, 18(2), 129-139.

Marsaulina, n., \& putra, r. J. (2018). Pengaruh modernisasi pelayanan perpajakan, sanksi perpajakan, kualitas pelayan pajakan, pengetahuan perpajakan kepada kepatuhan wajib pajak yang dimoderasi oleh sosialisasi perpajakan (studi kasus pada kpp pratama jakarta sunter). Media manajemen jasa, 6(1).

Ibrahim, a. (2016). Analisis implementasi manajemen kualitas dari kinerja operasional pada industri ekstraktif di sulawesi utara. Jurnal emba: jurnal riset ekonomi, manajemen, bisnis dan akuntansi, 4(2). 